\title{
PENDEKATAN KOMUNIKATIF DALAM PELAJARAN BAHASA ARAB
}

\author{
Oleh Taufiq Anshori, SS, M.Pd \\ E-mail taufiq86anshori@gmail.com
}

\begin{abstract}
The communicative approach in language learning emphasizes on the mastery of language proiciency. Communicative approach is based on some psychological theories of language and learning. The purpose of language learning, according to this approach, is factual communication, where students can use foreign language as a communication tool. In other words, the purpose of this approach is that students have the competence to communicate in a language they have learned in a variety of social situations. Communicative approach is also called the functional approach, in which the language is used as its functions. This article describes the application of communicative approach for teaching Arabic in Indonesian contexts.
\end{abstract}

Kata Kunci: pelajaran, bahasa Arab, pendekatan, komunikatif

\section{Pendahuluan}

Bahasa adalah ujaran (lisan) sehingga guru harus mengajarkan keterampilan berbahasa secara bertahap, dari menyimak (istimâ'), berbicara (kalâm), membaca (qirâ'ah), dan menulis (kitâbah). Dalam perspektif pedagogik, pelajaran keterampilan berbahasa hendaknya di-awali dengan penguasaan hal-hal yang terdekat dengan kehidupan pelajar, seperti penguasaan kosakata mengenai lingkungan sekolah, kelas, perpustakaan, dan sebagainya. Pelajaran sebaiknya dimulai atau diawali dengan yang mudah ke yang lebih sulit (gradual), memperhatikan ketepatan dalam penggunaan bahasa, dan menciptakan situasi yang menyenangkan. Menurut Kamal Ibrahim Badri dalam pendekatan audiolingual, ada lima prinsip yang perlu diketahui oleh pengajar bahasa asing menyebutnya sebagai metode pengajaran bahasa asing.

Pertama, bahasa adalah bicara bukan menulis. Pelajaran bahasa asing meng-utamakan keterampilan menyimak dan berbicara, lalu membaca dan menulis. Pengucapan huruf hijaiyah harus dibiasakan terlebih dahulu untuk menghindari pengaruh bahasa ibu.

Kedua, bahasa adalah sistem pembiasaan. Pelajaran bahasa asing diarahkan pada pembiasaan secara motoris dan releks, bukan pada pembuatan kalimat, misalnya dengan penuturan secara imitasi (peniruan) dan penghafalan.

Ketiga, mempelajari penggunaan bahasa bukan mempelajari tentang bahasa. Pelajaran dilatih menggunakan bahasa sesuai dengan objeknya. Pemberian kosa kata (mufradât) sangat diperlukan sesuai konteks.

Keempat, bahasa adalah apa yang dikatakan secara aktif bukan apa yang mesti dikatakan. Pelajar dibekali dengan ungkapan yang resmi (fushhâ) dan yang tidak resmi ('âmiyyah), serta pola kalimat dan contohnya yang bisa dipergunakan dalam berbicara, bukan materi perbedaan aksen (lahjah) antara satu daerah (Arab) dengan daerah lain secara mendetail.

Kelima, bahasa dalam penuturannya berbeda-beda. Pengucapan, susunan, dan semantik bahasa ibu itu berbeda dengan bahasa asing. Karena itu, pelajaran bahasa asing untuk pemula mengharuskan adanya tardî̀ (pengulangan ucapan huruf demi huruf) agar tidak terpengaruh dengan bahasa ibu sehingga pelajar dapat berbahasa secara otomatis dan refleks seolah-olah sebagai bahasa ibu sendiri.

Pandangan struktural dan audiolingual mengenai pendekatan dalam pelajaran bahasa mulai tersingkirkan oleh pendekatan-pendekatan baru, salah satunya pendekatan komunikatif. Asumsi belajar bahasa yang ditawarkan oleh pendekatan komunikatif adalah belajar berkomunikasi. Pelajaran bahasa di sekolah diarahkan untuk meningkatkan kemampuan siswa dalam berkomunikasi lisan dan tulisan. Bahasa sebagai sarana komunikasi yang digunakan dalam beragam fungsi dan disajikan dalam konteks yang bermakna, tidak dalam bentuk kalimat lepas 
sehingga mampu mewujudkan orientasi belajar mengajar bahasa yang berdasarkan tugas dan fungsi berkomunikasi.

Tulisan ini menjelaskan tentang gagasan dasar pendekatan komunikatif dalam pelajaran bahasa Arab dan penerapannya di madrasah-madrasah di Indonesia.

\section{Sejarah Kemunculan Pendekatan Komunikatif}

Pada tahun 1960-an mulai terjadi Gejala pergeseran pendekatan dalam pelajaran bahasa, ketika pendekatan audiolingual merajai benua Eropa dan Amerika. Namun, berbagai penemuan dalam bidang linguistik dan psikologi belajar menyebabkan metode audiolingual dan situasional yang berbasis teori linguistik struktural dan teori psikologi behavior mulai ditinggalkan sebagaimana yang terjadi pada tradisi pengajaran bahasa di Inggris.

Teori-teori linguistik struktural dan psikologi behavior yang menjadi asumsi dasar pengajaran bahasa sudah dianggap tidak cocok oleh ahli linguistik terapan. Penentang utama teori strukturalisme dan teori behaviorisme adalah Noam Chomsky. Dalam bukunya, Syntactic Structures (1957), Chomsky secara lugas menunjukkan bah-wa teori bahasa struktural standar saat itu terbukti tidak mampu menjelaskan karakteristik bahasa yang fundamental-kreativitas dan memiliki keunikan dalam setiap kalimatnya. Chomsky juga mengkritisi teori psikologi behavior dan menyatakan bahwa pelajaran bahasa tidak hanya ditentukan oleh faktor dari luar (eksternal), tetapi juga faktor dari dalam (internal). Sebab, setiap manusia memiliki kemampuan belajar bahasa yang dibawa sejak lahir yang disebut dengan jihâz iktisâb al-lughah atau Language Acquistion Device (LAD). Menurut Chomsky, proses belajar bahasa adalah proses pembentukan kaidah (rule formation process), bukan proses pembentukan kebiasaan (habit formation process). Ia berpendapat bahwa manusia memiliki apa yang disebut "innate capacity", suatu kemampuan untuk memahami dan menciptakan ungkapan-ungkapan baru.

Pendekatan komunikatif lahir dari situasi dimana pengajaran bahasa di Inggris yang mulai bergeser ke arah komunikatif. Pendekatan ini berakar pada tradisi linguistik dan prinsip pengajaran yang berkembang di Eropa, dan landasan teoretisnya diperkuat dengan teori belajar yang dikembangkan di Amerika Utara. Dua faktor utama yang berpengaruh terhadap kelahiran dan perkembangan pendekatan ini adalah surutnya popularitas metode audiolingual dan situasional di Inggris karena kecaman Chomsky dan makin eratnya kerjasama antara negaranegara Eropa dalam bidang kebudayaan dan pendidikan.

Semakin tinggi frekuensi perpindahan penduduk antarnegara di Eropa karena alasan imigrasi menyebabkan kerjasama yang erat antarnegara di Eropa Barat yang tergabung dalam European Common Market dan The Council of Europe. Dengan demikian, diperlukan pengajaran bahasa asing yang efektif dan bisa memenuhi kebutuhan berkomunikasi antar negara dan bangsa. Sementara itu, di Amerika Utara, berkembang aliran baru dalam pengajaran bahasa sebagai reaksi terhadap jatuhnya popularitas metode audiolingual. Kemudian di Kanada, dilakukan eksperimen pengajaran bahasa dengan sistem celup total (total immersion program). Dan, di Amerika Serikat, sejumlah penelitian melahirkan teori-teori pemerolehan bahasa kedua sebagai proses konstruksi kreatif (Dulay dan Burt, 1974) dan teori monitor (Krashen, 1981).

Situasi-situasi tersebut melatari mun-culnya pendekatan komunikatif. Sebab, kebutuhan komunikasi dengan bahasa asing berkembang dari ruang lingkup terbatas bagi penggunanya kepada ruang lingkup yang lebih luas bagi pengguna lainnya. Jadi, penyebab pergeseran dari pendekatan audiolingual ke pendekatan komunikatif adalah faktor kebutuhan komunikasi.

Sejalan dengan Wilkins, Subyakto-N (1988) dalam Nurul Murtadho (1991) menyatakan bahwa ada dua hal yang paling mendasar dalam pendekatan komunikatif, yaitu: Pertama, kebermaknaan dalam setiap bentuk bahasa yang dipelajari, kedua keterkaitan antara bentuk, ragam, dan makna bahasa dengan situasi dan konteks berbahasa. Hal pertama menjadikan semua bentuk bahasa (kata, frasa, dan kalimat) dan struktur bahasa (urutan kata, imbuhan, dan kategori struktur seperti istilah dalam bahasa Arab: isim, iil, huruf dan sebagainya) akan selalu berkaitan dengan makna. Sebab, bahasa adalah pengungkapan ide, konsep, atau nosi. Dalam hal ini, pendekatan komunikatif masih memperhatikan aspek gramatika yang bersifat fungsional. Hal 
kedua menjadikan bentuk dan makna bahasa terkait dengan situasi dan konteks penggunaan bahasa sehingga aspek sosiolinguistik menjadi latar dan situasi terjadinya penggunaan bahasa.

\section{Konsep Dasar Pendekatan Komunikatif}

Pada dasarnya, pendekatan komunikatif merupakan pendekatan pelajaran bahasa yang lebih menekankan pelajaran pada penguasaan kecakapan berbahasa daripada penguasaan struktur bahasa. Beberapa pendukung gagasan ini, antara lain: ahli pelajaran Inggris Christopher Chandlin dan Henry Widdowson, linguis fungsional Inggris John Firth dan M.A.K. Halliday, sosiolinguis Amerika Dell Hymes, John Gumperz, dan William Labov, dan ahli ilsafat Amerika John Austin dan John Searle.Konsep dasar yang diusung oleh para pakar pendekatan ini bermuara perlunya kompetensi komunikatif.

E. Sadtono dalam Muljanto Sumardi (1996) mendefinisikan kompetensi sebagai penguasaan suatu sistem aturan bahasa yang benar-benar dihayati, yang memungkinkan kita untuk mengenal struktur batin dan lahir, untuk dapat membedakan antara kalimat yang benar maupun kalimat yang salah, dan untuk mengerti kalimat-kalimat yang belum pernah kita dengar atau kita katakan sebelumnya.

Kompetensi komunikatif adalah kemampuan untuk menerapkan kaidah gramatikal suatu bahasa dalam membentuk kalimat yang benar dan untuk mengetahui atau menetapkan kapan, di mana, dan kepada siapa kalimat itu diujarkan. Dengan berbekal kompetensi komunikatif, seseorang dapat menyampaikan dan menginterpretasikan suatu pesan atau menegosiasikan makna secara interpersonal dalam konteks yang spesifik. Krashen juga menegaskan bahwa kompetensi komunikatif lebih menekankan fungsi bahasa dalam komunikasi sesungguhnya daripada menguasai bentuk dan kaidah kebahasaan. Kaidah-kaidah kebahasaan itu hanya berfungsi untuk memonitor suatu bentuk ujaran.

Menurut Tarigan, pada hakikatnya kompetensi komunikatif meliputi:

a. Pengetahuan mengenai tata bahasa dan kosakata bahasa yang bersangkutan.

b. Pengetahuan mengenai kaidah-kaidah berbicara (yaitu mengetahui bagaimana memulai dan mengakhiri percakapan-percakapan, mengetahui topik apa yang mungkin dibicarakan dalam berbagai peristiwa-bicara, mengetahui bentuk-bentuk sapaaan yang seharusnya dipakai kepada orang lain dalam berbagai sistuasi).

c. Mengetahui bagaimana cara meng-gunakan dan memberi respon terhadap berbagai tipe tindak tutur, seperti meminta, memohon, meminta maaf, mengucapkan terima kasih, dan mengundang orang.

d. Mengetahui bagaimana cara meng-gunakan bahasa secara tepat dan memuaskan.

Salah satu prinsip pelajaran komunikatif yang dikemukakan oleh Canale dan Swain (1980) adalah bahwa kemampuan berbahasa anak sangat ditentukan oleh tingkat penguasaan kompetensi komunikatif yang terdiri atas empat kompetensi berikut:

a. Kompetensi gramatikal, yaitu penge-tahuan dan kemampuan dalam bidang tatabunyi, kosakata, serta tatabahasa.

b. Kompetensi sosiolinguistik, yaitu pengu-asaan memilih bentuk komunikasi yang sesuai dengan mitra bicara, tempat, suasana, saluran komunikasi, serta aspek lain yang harus dipertimbangkan dalam berkomunikasi.

c. Kompetensi kewacanaan, yaitu kemam-puan untuk menafsirkan rangkaian kalimat atau ungkapan dalam rangka membangun keutuhan makna dan keterpaduan teks sesuai dengan konteksnya.

d. Kompetensi strategis, yaitu keberanian, rasa percaya diri, kemampuan ber-bagi peran dengan lawan bicara, pemanfaatan peluang untuk berbicara, dan sebagainya.

Pendekatan komunikatif berbasis pada sejumlah teori bahasa dan psikologi belajar yang bertujuan untuk mencapai komunikasi faktual, yaitu siswa dapat menggunakan bahasa asing yang dipelajari 
sebagai alat komunikasi. Dengan kata lain, tujuan pendekatan ini adalah agar siswa memiliki kompetensi berkomunikasi dengan meng-gunakan bahasa yang dipelajarinya dalam berbagai situasi sosial.

Karena pada hakikatnya tujuan pengajaran dalam pendekatan komunikatif merupakan untuk berkomunikasi, maka kemampuan bahasa yang dikembangkan adalah kemampuan berkomunikasi, bukan kemampuan tentang pengetahuan bahasa. Widdowson membedakan kemampuan berbahasa dengan kemampuan tentang bahasa. Kemampuan berbahasa adalah kemampuan yang dimiliki oleh pembicara dan pendengar untuk memahami dan memproduksi bahasa ucapan dan saling mengerti. Sedangkan, kemampuan tentang bahasa ialah kemampuan umum untuk mempelajari dan mengenal semua ungkapan bahasa yang benar dan baik walaupun tidak mampu mengucapkan atau menggunakannya. Jadi, kompetensi bahasa dan berbahasa Arab yang harus dimiliki pelajar adalah mampu memahami pesan-pesan yang diucapkan dalam bahasa Arab, mampu secara spontan mengucapkan atau menggunakan ungkapan berbahasa Arab untuk merespons pesan-pesan dengan tepat, mampu menyatakan keinginan, kebutuhan, atau hasratnya tanpa harus dirangsang terus oleh guru, dan mampu memproduksi ungkapan tersebut dengan memadukan sistem ucapan, tata bahasa, dan kosakata di dalam situasi budaya bahasa yang digunakan secara normal seperti yang dipakai oleh penutur asli.

Kompetensi komunikatif meliputi pengetahuan penggunaan bahasa dan kemampuan menggunakannya dalam berbagai konteks atau situasi komunikasi. Savignon menyebutkan lima karakteristik kompetensi komunikatif berikut:

a. Kompetensi komunikatif bersifat di-namis, bergantung pada negosiasi makna antara dua penutur atau lebih yang sama-sama mengetahui kaidah pemakaian bahasa. Dalam pengertian ini kemampuan komunikasi dapat dikatakan bersifat interpersonal.

b. Kompetensi komunikatif meliputi pe-makaian bahasa, baik secara tertulis maupun lisan, juga sistem simbolik yang lain.

c. Kompetensi komunikatif bersifat kon-tekstual. Komunikasi selalu terjadi pada variasi situasi tertentu. Keberhasilan komunikasi bergantung pada pe-ngetahuan partisipan terhadap konteks dan pengalaman.

d. Berkaitan dengan dikotomi kompetensi dan performansi, kompetensi mengacu pada apa yang diketahui, sedangkan performansi mengacu pada apa yang dilakukan. Hanya performansi saja yang dapat diamati. Hanya melalui performansi, kompetensi dapat di-kembangkan, dipertahankan dan di-evaluasi.

e. Kompetensi komunikatif bersifat relatif, tidak absolut dan bergantung pada kerja sama atau partisipan. Hal inilah yang menyebabkan adanya tingkat-tingkat kompetensi komunikatif.

Berkaitan dengan kompetensi ber-bahasa, Bachman (1990) menawarkan model kemampuan bahasa komunikatif (communicative language ability). Bachman membagi kompetensi bahasa kepada dua kategori utama: kompetensi organisasional dan kompetensi pragmatik. Kompetensi organisasional dibagi lagi menjadi kom-petensi gramatikal dan kompetensi tekstual. Begitu juga kompetensi pragmatik dibagi lagi menjadi kompetensi ilokusi dan kompetensi sosiolinguistik. Kompetensi ilokusi adalah kemampuan untuk memahami dampak yang dikehendaki oleh penutur pada petutur.

Model Bachman di atas dirinci lagi oleh Bachman \& Palmer (1996) yang mengajukan kerangka analisis area pengetahuan bahasa berikut:

\section{a. Pengetahuan Organisasional (Organizational Knowledge)}

Pengetahuan ini menjelaskan bagaimana ujaran atau kalimat dan teks ditata, yang meliputi:

- Pengetahuan gramatika yang mencakup: pengetahuan tentang kosakata, pengetahuan tentang morfologi, pengetahuan tentang sintaksis, dan pengetahuan tentang fonologi/grafologi. 
- Pengetahuan Tekstual (bagaimana ujaran atau kalimat ditata untuk membentuk teks) yang mencakup: pengetahuan tentang kohesi dan pengetahuan tentang penataan retorikal dan percakapan.

\section{b. Pengetahuan Pragmatik (Pragmatic Knowledge)}

Pengetahuan ini menjelaskan bagai-mana ujaran atau kalimat dan teks dihubungkan untuk mencapai tujuan-tujuan komunikasi oleh pengguna bahasa dan dihubungkan dengan ciri-ciri lingkungan bahasa. Pengetahuan pragmatik mencakup:

- Pengetahuan Fungsional (bagai-mana ujaran atau kalimat dan teks dihubungkan untuk mencapai tujuan komunikasi oleh pengguna bahasa). Pengetahuan ini mencakup:

(a) pengetahuan tentang fungsi-fungsi ideasional, (b) pengetahuan tentang fungsifungsi manipulatif,

(c) pengetahuan tentang fungsi-fungsi heuristik, (d) pengetahuan tentang fungsi-fungsi imajinatif.

- Pengetahuan Sosiolinguistik (bagai-mana ujaran atau kalimat dan teks dihubungkan dengan ciri-ciri lingkungan penggunaan bahasa). Pengetahuan ini mencakup: (a) pengetahuan tentang dialek/ keragaman bahasa, (b) pengetahuan tentang register, (c) pengetahuan tentang ekspresi natural dan idiomatik, (d) pengetahuan tentang acuan budaya dan kiasan.

\section{Asumsi dan Prinsip Pendekatan Komunikatif}

Menurut Ahmad Fuad Effendi, dalam pendekatan komunikatif memiliki beberapa asumsi berikut:

1). Setiap manusia memiliki kemampuan bawaan yang disebut dengan language acquisition devide (LAD). Oleh karena itu, kemampuan bahasa bersifat kreatif dan lebih ditentukan faktor internal.

2). Pengguna bahasa tidak hanya terdiri atas empat keterampilan: menyimak, berbicara, membaca, dan menulis. Tetapi, mencakup beberapa kemampuan dalam kerangka komuniktif yang luas sesuai dengan peran peserta, situasi, dan tujuan interaksi.

3). Belajar bahasa kedua dan bahasa asing sama dengan belajar bahasa pertama, yaitu berangkat dari kebutuhan dan minat siswa. Oleh karena itu, analisis kebutuhan dan minat siswa merupakan landasan pengembangan bahan ajar.

Dari asumsi di atas, dapat dikatakan bahwa pelajar bahasa asing (Arab) telah memiliki kemampuan bahasa yang bersifat kreatif, yang bisa dibangkitkan dengan pendekatan internal, yaitu memunculkan minat belajar bahasa Arab. Untuk memunculkan minat, diperlukan motivasi eksternal berupa penciptaan peran pelajar yang lebih luas dan situasi yang mendukung guna mencapai tujuan interaksi dalam komunikasi yang dikehendaki. Karena itu, perlu dirancang kegiatan untuk mengetahui kebutuhan dan minat pelajar terhadap bahasa, misalnya dengan analisis kebutuhan dan minat.

Tentang prinsip pendekatan komunikatif ini, Angela Scarino dkk (1994) berpandangan bahwa tujuan utama semua pelajaran bahasa adalah membantu pelajar mampu menggunakan bahasa target yang bisa dicapai dengan berbagai cara dan pendekatan. Untuk mencapai tujuan tersebut, seorang guru harus mengetahui prinsip-prinsip belajar bahasa yang harus diwujudkan ke dalam kegiatan pengajarannya. Ringkasnya, prinsip pendekatan komunikatif menurut Scarino dkk adalah: pelajar akan belajar bahasa dengan baik apabila berada dalam delapan kondisi berikut:

1) ia diperlakukan sebagai individu yang memiliki kebutuhan dan minat;

2) ia diberi kesempatan untuk ber-partisipasi dalam penggunaan bahasa sasaran secara komunikatif dalam beragam aktivitas;

3) ia ditunjukkan pada data komunikatif yang bisa dipahami dan relevan dengan kebutuhan dan minatnya; 
4) ia secara sengaja memfokuskan pem-belajarannya pada bentuk, keterampilan, dan strategi yang mendukung proses pemerolehan bahasa;

5) ia dibeberkan dalam data sosiokultural dan pengalaman langsung dengan budaya yang menjadi bagian dari bahasa sasaran;

6) ia menyadari akan peran dan hakikat bahasa dan budaya;

7) ia diberi umpan balik yang tepat menyangkut kemajuan belajarnya;

8) ia diberi kesempatan untuk mengatur pelajarannya sendiri.

Littlewood (1981) lebih merinci prinsip-prinsip pengajaran bahasa dalam pendekatan komunikatif sebagai berikut:

1) Bahasa yang disajikan adalah bahasa yang autentik, dipergunakan dalam realita kontekstual.

2) Bahasa tersebut dapat dipahami mak-sudnya oleh pembicara atau penulis sebagai bagian dari kompetensi komunikatif.

3) Sasaran bahasa adalah wahana untuk komunikasi kelas, bukan sekadar objek belajar.

4) Satu fungsi dapat memiliki beberapa bentuk bahasa; fokus belajarnya bahasa yang digunakan secara realita; dan varian bentuk bahasa disajikan bersama-sama.

5) Pelajar mempelajari kalimat dalam suatu wacana, seperti kohesi dan koherensi.

6) Pelajar dapat menentukan ke-adaan belajar sesuai dengan realita komunikatif sehingga pembicara dapat langsung menerima umpan balik dari pendengar.

7) Pelajar diberi kesempatan untuk mengekspresikan ide dan opini mereka.

8) Kekeliruan dapat diterima dan di-nilai sebagai hal yang alami dalam pengembangan keterampilan komunikasi.

9) Guru bertanggung jawab dalam me-nentukan situasi yang disukai untuk pengembangan komunikasi.

10) Interaksi komunikasi mendorong hubungan kerjasama antarpelajar. Interaksi ini merupakan kesempatan bagi pelajar untuk memahami atau negosiasi makna.

11) Konteks sosial dalam even komunikasi merupakan hal penting dalam pe-ngungkapan makna yang diberikan.

12) Belajar menggunakan bahasa yang tepat merupakan bagian penting dalam kompetensi komunikatif. Guru berlaku sebagai pembimbing dalam aktivitas komunikasi.

13) Dalam komunikasi, pembicara dapat memilih tentang apa yang dikatakan dan bagaimana mengatakannnya.

14) Para pelajar mempelajari gramatika dan kosakata melalui fungsi, konteks situasional, dan peran pada teman bicara.

15) Para pelajar diberikan ruang untuk mengembangkan strategi dalam memahami bahasa sebagaimana yang digunakan para penutur bahasa tersebut.

\section{Ciri-ciri Pendekatan Komunikatif}

Ciri-ciri pelaksanaan pendekatan komunikatif menurut Finochiaro dan Brum it (1983), adalah sebagai berikut:

1) Makna sangat penting;

2) Dialog, bila digunakan, berpusat pada fungsi komunikatif dan biasanya tidak dihafalkan;

3) Kontekstualisasi merupakan pernyataan dasar; 
4) Belajar bahasa berarti belajar ber-komunikasi;

5) Komunikasi efektif diupayakan;

6) Pengulangan bisa dipakai, tetapi tidak sentral;

7) Pengucapan diusahakan yang bisa dipahami;

8) Usaha untuk berkomunikasi bisa didorong dari awal;

9) Penggunaan bahasa ibu yang bijaksana diperbolehkan jika dibutuhkan;

10) Penerjemahan bisa digunakan bila bermanfaat bagi pelajar;

11) Membaca dan menulis bisa dimulai sejak hari pertama;

12) Kompetensi komunikatif menjadi tu-juan pelajaran yang sejalan dengan kemampuan menggunakan sistem linguistik secara efektif;

13) Variasi bahasa dijadikan konsep sentral dalam bahan ajar dan metodologi;

14) Urutan ditentukan oleh pertimbangan isi, fungsi, atau makna yang mengikat minat;

15) Guru membantu dan memotivasi pelajar dengan cara apa pun;

16) Bahasa diciptakan oleh individu yang sering mencoba dan meralat (trial and error);

17) Kefasihan bahasa yang bisa dipahami adalah tujuan utama; akurasi dinilai dari konteks bukan abstrak;

18) Pelajar berinteraksi secara lisan dan tulisan dengan orang lain, baik secara langsung maupun tidak langsung, berpasangan atau kelompok;

19) Guru tidak mengetahui secara pasti bahasa apa yang akan digunakan pelajar;

20) Motivasi instrinsik akan muncul dari minat terhadap apa yang sedang dikomunikasikan dalam bahasa tersebut.

Lebih ringkas, Richards \& Rodgers

menyebutkan ciri-ciri penggunaan pendekatan komunikatif berikut:

1) Bahasa adalah suatu sistem bagi ekspresi makna.

2) Fungsi utama bahasa adalah untuk interaksi dan komunikasi.

3) Struktur bahasa mencerminkan peng-gunaan fungsional dan komunikatif.

4) Unit-unit bahasa tidak semata berupa ciri-ciri gramatikal dan struktural tetapi kategori makna fungsional dan komunikatif seperti dalam wacana.

\section{Teori Belajar Bahasa Pendekatan Komunikatif}

Teori belajar yang mendasari pendekatan komunikatif adalah teori pemerolehan bahasa kedua secara alamiah yang berkembang di Amerika Utara setelah tahun 1970. Menurut Stern, dalam Huda (1987), pendukung teori ini beranggapan bahwa proses belajar bahasa lebih efektif bila bahasa itu diajarkan secara informal melalui komunikasi langsung dalam bahasa sasaran. Sebab, pengajaran bahasa secara formal cenderung mengarahkan pem-belajar untuk mendapatkan pengetahuan atau keterampilan bahasa tetapi tidak mengarahkan penggunaan keterampilan berbahasa itu. Stern mengemukakan bahwa pada waktu berbicara, perhatian pembaca ditujukan kepada pesan yang disampaikan, bukan pada kode-kode formal bahasa. Dan, pengajaran yang menekankan penguasaan kode-kode formal (gramatika) itu tidak berhasil membuat pelajar menggunakan bahasa dalam situasi komunikasi yang sebenarnya. Pengajaran bahasa dengan pendekatan komunikatif harus mengarahkan pelajar untuk menguasai bahasa dalam konteks komunikatif.

Teori selanjutnya yang mendukung pendekatan komunikatif adalah teori Krashen yang membedakan dua cara pemerolehan bahasa kedua bagi orang dewasa. Cara pertama disebut dengan pemerolehan (acquisition), yaitu ber-langsung secara informal seperti seorang anak kecil 
belajar bahasa ibunya. Cara kedua disebut dengan belajar (learning), yaitu berlangsung melalui pengajaran formal dalam kelas tentang aturan-aturan tata bahasa. Krashen menjelaskan, bahwa pemerolehan merujuk kepada perkembangan sistem bahasa sasaran yang tidak disadari akibat dari penggunaan bahasa tersebut untuk maksud komunikasi nyata. Sebaliknya, pelajaran merupakan proses penguasaan gramatikal yang disadari sebagai hasil pengajaran, dan ia tidak bisa mengarah kepada pemerolehan. Jadi, pemerolehan bahasa kedua menjadi landasan yang kuat bagi pengajaran bahasa komunikatif.

Para ahli pemerolehan bahasa kedua berbeda pandangan tentang perbedaan individu pelajar. Fillmore (1994) me-nyebutkan dua pandangan berikut:

1) Perbedaan individu adalah hal penting dalam proses pemerolehan bahasa kedua karena akan memunculkan interaksi antarpelajar.

2) Perbedaan individu tidak penting karena pemerolehan bahasa kedua dianggap sama seperti pemerolehan bahasa pertama.

Hasil kajian Fillmore menunjukkan bahwa keragaman individu itu penting dalam proses pemerolehan bahasa kedua, dan bahwa keragaman itu berhubungan dengan faktor sosial dan kognitif pemerolehan bahasa kedua yang saling berinteraksi.

\section{Desain Pengajaran Bahasa Komunikatif}

Desain pengajaran bahasa secara komunikatif mencakup beberapa hal yaitu tujuan pelajaran, silabus, aktivitas belajar mengajar, dan peran siswa, guru, dan bahan ajar.

\section{Tujuan Pelajaran}

Tujuan pelajaran bahasa pendekatan komunikatif adalah mengantarkan siswa menuju pencapaian kompetensi berbahasa dalam berbagai situasi. Menurut Canale \& Swain (1980), tujuan pengajaran bahasa komunikatif adalah memberikan siswa informasi, praktik, dan pengalaman yang diperlukan untuk kepentingan komu-nikasinya. Pengajaran bahasa secara komunikatif dapat membangkitkan kemampuan mencipta kalimat-kalimat gramatika, kemampuan memasukkan aspek pragmatik ke dalam keterampilan berbahasa, dan kemampuan menyesuaikan ujaran dengan komunikasi.

Menurut Azies dan Alwasilah, tujuan khusus pengajaran bahasa komunikatif bergantung pada kebutuhan si belajar. Dalam kurikulum, tujuan pengajaran biasanya mencerminkan aspek tertentu dari kompetensi komunikatif yang sesuai dengan tingkat kemahiran dan kebutuhan komunikatif pelajar.

\section{Silabus}

Silabus adalah rencana pelajaran pada suatu dan/atau kelompok mata kuliah/tema tertentu yang mencakup standar kompetensi, kompetensi dasar, materi pokok/pelajaran, pengalaman belajar (kegiatan pelajaran), pen-capaian indikator, penilaian, alokasi waktu, dan sumber/referensi belajar. Menurut Masnur Muslich, silabus adalah produk pengembangan kurikulum yang menjabarkan standar kompetensi dan kompetensi dasar yang ingin dicapai, serta pokok-pokok dan uraian materi yang perlu dipelajari siswa dalam rangka mencapai standar kompetensi dan kompetensi dasar.

Pendekatan komunikatif memiliki desain silabus berikut:

a. Silabus fungsional-nosional yang merupakan komunikatif murni yang diarahkan langsung kepada pe-ngembangan keterampilan komunikasi. Yang termasuk dalam kelompok ini antara lain Alexander (1975), Van Ek (1975, 1976), Mills (1978) dan Mumby (1978).

b. Silabus nosional, berorientasi pada semantik-gramatikal yang dikem-bangkan untuk mengatasi kelemahan-kelemahan silabus struktur. Silabus yang merupakan perjalinan di antara tatabahasa dan fungsi nosi. Yang termasuk dalam kelompok ini antara lain Wilkins (1974), Valdman (1978, 1980), Brum it (1980), Maley (1980,1981), Maley (1980), Paulston (1981), dan Higgs dan Clifford (1982). 
c. Silabus situasional atau silabus yang fleksibel. Tatabahasa dan fungsi disusun saling berkaitan dan saling bergantung. Dari aspek materinya dipilih ber-dasarkan prediksi tentang situasi yang mungkin ditemui oleh pelajar. Yang termasuk dalam kelompok ini antara lain Shaw (1979), Allen (1980) dan Yalden (1980).

Kelompok pertama terlalu ekstrem ka-rena meninggalkan sama sekali gramatika. Kelompok kedua berupaya menjalin gramatika dan fungsi-nosi. Antara gramatika dan fungsi-nosi memiliki kedudukan yang linier atau sejajar. Sementara, kelompok ketiga tidak tegas karena bisa condong ke gramatika dan bisa ke fungsi-nosi.

Dalam konteks pelajaran ba-hasa Arab bagi masyarakat Indonesia, pendekatan komunikatif memiliki asumsi bahwa kemampuan bahasa bersifat kreatif, bahasa fungsional bergantung pada situasi, dan pelajaran bahasa kedua/asing (Arab) harus berangkat dari kebutuhan dan minat pelajar. Karena itu, silabus yang tepat digunakan adalah silabus situasional atau leksibel. Sebab, menurut Howatt dalam Thu'aimah dan al-Naqah (2006), pendekatan komunikatif mempunyai dua versi, yaitu pertama, versi lemah (weak version), yakni dalam pelajaran bahasa asing, pelajar diberi kesempatan menggunakan bahasa untuk tujuan komunikasi. Kedua, versi kuat (strong version), yakni mempelajari bahasa untuk memperoleh komunikasi murni.

Menurut Yalden (1987), penyusunan desain silabus komunikatif harus melibatkan sejumlah faktor di luar linguistik, seperti lingkungan pendidikan, karakteristik pelajar, keadaan institusi penyelenggara pendidikan, bahkan masyarakat tempat proses pelajaran bahasa. Yalden menawarkan prinsip penyusunan silabus komunikatif yang mencakup:

a. Pertimbangan yang serinci mungkin mengenai tujuan yang akan diperoleh oleh para pelajar dalam bahasa sasaran;

b. Beberapa gagasan mengenai lingkungan yang merupakan wadah mereka akan menggunakan bahasa sasaran;

c. Peranan yang dibatasi secara sosial yang akan dimainkan oleh para pelajar di dalam bahasa sasaran di samping peranan lawan bicara mereka;

d. Peristiwa-peristiwa komunikatif yang merupakan wadah para pelajar akan berpartisipasi: situasi sehari-hari, situasi profesi, situasi akademik, dan sebagainya;

e. Fungsi-fungsi bahasa yang terlibat dalam peristiwa-peristiwa tersebut, atau apa yang perlu dapat dilakukan dengan dan melalui bahasa sasaran tersebut;

f. Nosi-nosi yang terlibat, atau apa yang perlu dapat diperbincangkan oleh pelajar;

g. Keterampilan-keterampilan yang ter-libat dalam penyatupaduan wacana; keterampilanketerampilan berwacana dan retoris;

h. Variasi bahasa sasaran yang akan diperlukan dan tingkatan dalam bahasa lisan dan bahasa tulisan yang perlu dicapai oleh para pelajar;

i. Unsur-unsur gramatikal yang akan di-perlukan;

j. Unsur-unsur leksikal yang akan di-perlukan.

\section{Aktivitas Belajar Mengajar}

Aktivitas belajar-mengajar pada pendekatan komunikatif menekankan pembinaan dan pengembangan kom-petensi komunikatif. Nababan (1993) mengungkapkan bahwa hanya aktivitas komunikasi realistis yang mendorong pelajar beraktivitas dengan bahasa yang dipelajarinya sehingga mencapai tugas yang bermakna. Azies dan Alwasilah (2000)

sesuai dengan pendekatan komunikatif tidak terbatas, asalkan pelatihan itu membantu pelajar meraih tujuan komunikatif yang ada dalam kurikulum, melibatkan pelajar dalam berkomunikasi, dan menggunakan proses-proses komunikatif.

Selanjutnya, Morrow mengatakan bahwa aktivitas yang betul-betul komunikatif harus memenuhi beberapa kriteria, yaitu: ada kesenjangan informasi, ada pemilihan, dan ada umpan balik. Kesenjangan informasi terjadi jika ada pertukaran informasi tertentu. Selain itu, aktivitas di dalam kelas memberi kesempatan kepada pelajar untuk menggunakan bahasa secara kreatif dengan cara memilih bebas apa 
yang diungkapkan dan bagaimana pengungkapannya. Dalam komunikasi yang komunikatif melalui umpan balik yang diberikan oleh penerima, pembicara dapat mengevaluasi apakah tujuan pembicaraan telah tercapai atau belum.

\section{Peran Siswa, Guru, dan Bahan Ajar}

Menurut Candlin, peran siswa dalam pelajaran berbasis komunikatif adalah sebagai negosiator antara dirinya, proses belajar, dan objek pelajaran sehingga dapat berinteraksi dengan peran negosiator bersama dalam kelompok serta dalam prosedur dan aktivitas kelas yang dijalani kelompok. Peran negosiator adalah semua yang terlibat dalam proses pelajaran harus mengakui bahwa siswa sudah memiliki referensi pelajaran yang semestinya. Peran ini akan mempengaruhi dan sekaligus dipengaruhi oleh negosiator yang bergabung dengan kelompoknya sehingga mewarnai prosedur dan aktivitas belajar secara keseluruhan.

Baradja (1990) menegaskan bahwa siswa diharapkan memiliki motivasi yang tinggi dalam penggunaan bahasa kedua. Mereka didorong untuk mendapatkan sebanyak mungkin masukan dari segala sumber, harus tahu apa yang akan dilakukan, memahami tujuan pengajaran, dan dihormati sebagai teman serta tidak boleh merasa takut dalam menggunakan bahasa target.

Guru berperan sebagai fasilitator, didalam pendekatan komunikatif ini. Sebagai individu yang mengetahui arah pengajaran, guru berperan dan mengkoordinasi kegiatan siswa. Untuk mencapai tujuan pengajaran, terutama dalam pengajaran membaca dan menulis, guru bisa juga berperan sebagai pengajar biasa: menyajikan materi, memberikan latihan, melakukan evaluasi, dan memberikan umpan balik.

Breen dan Candlin (1980), dalam Azies dan Alwasilah, menambahkan bahwa guru memiliki dua peran utama, yaitu (1) mempermudah komunikasi antarsemua siswa di kelas dan antarpeserta dalam teks disertai beragam aktivitas, (2) bertindak sebagai partisipan independen dalam kelompok belajar mengajar.

Selanjutnya, bahan ajar atau materi pelajaran harus diambil dari sampel bahan yang otentik, yaitu sampel yang diambil dari penggunaan bahasa dalam konteks komunikasi sesungguhnya. Tidak ada satu buku teks yang diwajibkan atau dianjurkan. Buku teks, rekaman kaset, atau apa pun yang dapat membantu mencapai tujuan langsung proses belajar mengajar dapat digunakan.

Richards \& Rodgers menyebutkan tiga jenis utama bahan ajar yang digunakan di dalam pengajaran bahasa komunikatif, yaitu (1) bahan ajar tekstual, seperti buku Communicate (1979) karya Morrow dan Johnson yang tidak memiliki satu pun dialog, pengulangan, atau pola kalimat seperti biasanya, (2) bahan ajar tugas, yaitu bahan ajar yang berisi permainan, simulasi, dan aktivitas berdasarkan tugas yang telah disiapkan untuk menunjang pengajaran bahasa komunikatif, dan (3) bahan ajar realitas, yaitu bahan-bahan otentik dari kehidupan dalam ruang kelas, seperti yang bersumber dari majalah iklan, surat kabar, atau sumber-sumber visual dan gra is.

\section{Prosedur Pengajaran Bahasa Komunikatif}

Azies dan Alwasilah mengemukakan bahwa prosedur pengajaran pendekatan komunikatif itu sulit dilakukan karena dua faktor. Pertama, prinsip-prinsip komunikatif bisa diaplikasikan dalam pengajaran semua keterampilan. Kedua, terdapat keragaman yang luas pada aktivitas dan jenis-jenis latihan yang dibahas dalam literatur pengajaran bahasa komunikatif. Namun, ada beberapa prosedur umum pengajaran bahasa komunikatif yang dikembangkan para ahli, seperti Finochairo dan Brum it (1993) yang menawarkan garis besar pengajaran fungsi bahasa (making suggestion) bagi pelajaran tingkat awal sekolah menengah pertama yang dilanjutkan Harmer dengan communication continum.

Prosedur pelajaran bahasa komunikatif menurut Finochairo dan Brum it adalah sebagai berikut:

1. penyajian dialog singkat yang didahului pembangkitan motivasi siswa berkaitan dengan situasi, fungsi dialog, dan latar belakang pengalaman; 
2. pelatihan oral secara kelompok dan individu;

3. tanya jawab berkaitan topik dan situasi dialog;

4. tanya jawab tentang pengalaman pribadi siswa terkait tema dialog;

5. pembahasan satu ungkapan atau struk-tur dari luar dialog dalam bentuk dialog singkat yang lain;

6. penemuan dan re leksi siswa pada kaidah yang mendasari ungkapan fungsional atau struktur;

7. pengenalan lisan atau aktivitas inter-pretatif;

8. aktivitas produksi lisan, mulai dari yang terbimbing hingga yang lebih bebas;

9. menyalin dialog singkat dalam modul atau teks pelajaran;

10. pemberian tugas tulis untuk pekerjaan rumah (bila ada); dan

11. evaluasi pelajaran secara lisan.

Selanjutnya, Alexander (1978) dalam Mainline Beginner menganjurkan prosedur yang memasukkan butir-butir pengajaran baru dalam dialog, tetapi setiap unit mempunyai fokus fungsional yang jelas. Prosedur ini dimulai dengan pelatihan pola-pola gramatikal utama secara terkontrol, lalu kontekstualisasi butir-butir pengajaran melalui latihan situasional yang diikuti pelatihan lebih bebas seperti main peran atau improvisasi.

Dengan demikian, prosedur pengajaran berdasarkan pendekatan komunikatif masih bervariasi. Karena itu, guru dapat memilih prosedur yang cocok, memodi ikasinya, atau menciptakan sendiri prosedur yang sesuai dengan situasi dan kebutuhannya.

\section{Evaluasi Pengajaran bahasa Komunikatif}

Evaluasi merupakan proses penilaian. Evaluasi, menurut Gronlund dan Linn, adalah suatu proses sistematis dalam mengumpulkan, menganalisis, dan menafsirkan data-data untuk menentukan apakah seorang peserta didik dipandang telah mencapai target pengetahuan atau keterampilan yang dirumuskan dalam tujuan pengajaran.

Suchman memandang evaluasi sebagai proses menentukan hasil dari beberapa kegiatan yang telah direncanakan untuk mendukung tercapainya tujuan. Ia merupakan kegiatan-informasi tentang bekerjanya sesuatu untuk menentukan alternatif pengambilan keputusan. Dari proses penilaian atau evaluasi, akan diperoleh data tentang: pencapaian tujuan pelajaran, efektivitas metode dan model yang dipergunakan dalam pelajaran, perubahan tingkah laku siswa sesuai tujuan pelajaran, dan feed back yang bermanfaat bagi guru untuk perbaikan pelajaran.Untuk mengukur pencapai tujuan itu diperlukan antara lain tes yang baik.

Dalam pengajaran bahasa komunikatif, tes yang digunakan untuk mengukur hasil dan kemajuan belajar adalah tes komunikatif. Tes-tes bahasa berdasarkan pendekatan komunikatif memiliki keotentikan tinggi apabila mengakomodasi prinsip pemakaian bahasa sehari-hari dan bahan-bahan tesnya digunakan alami atau tidak dimanipulasi, seperti bacaan dari majalah dan surat kabar, rekaman acara radio atau televisi, dan tugas-tugas yang mendekati keadaan sebenarnya, seperti interviu, pidato, menulis surat yang mengandung unsur sosiolinguistik dan sebagainya. Djiwandono (2008) menegaskan bahwa penggunaan bentuk tes komunikatif hendaknya beragam; penggunaan bentuk tes tertentu hanya cocok untuk variasi bahasa tertentu; dan penggunaan tes beragam bisa menjangkau berbagai variasi bahasa sesuai dengan hakikat penggunaan bahasa dalam berkomunikasi.

Penerapan kemampuan komunikatif pada tes bahasa komunikatif harus didasarkan pada rincian rumusan yang banyak digunakan, yang memahami kemampuan komunikatif itu terdiri dari kemampuan linguistik, sosiolinguistik, wacana, dan trategis.

Adapun ciri-ciri tes bahasa dengan pendekatan komunikatif adalah:

a. Isi dan pilihan topik beragam sesuai dengan latar belakang dan tujuan.

b. Sumber pemilihan bahan penguasaan bahasa diorientasikan pada bidang kajian umum akademik dan penggunaan bahasa sehari-hari. 
c. Jenis bahan rujukan berasal dari buku, jurnal, majalah, dan surat kabar.

d. Jenis dan format tes beragam, termasuk subjektif dan objektif, tanpa pertanyaan dengan jawaban ya-tidak, monolog, interviu, dan pembicaraan dengan penguji. 
madrasah harus diarahkan untuk meningkatkan kemampuan siswa dalam berkomunikasi, baik secara lisan maupun tulisan. Bahasa sebagai sarana komunikasi digunakan dalam bermacammacam fungsi dan disajikan dalam konteks yang bermakna, tidak dalam bentuk kalimat lepas.

2. Terdapat dua corak pendekatan komunikatif. Pertama, yang masih mementingkan aspek gramatika yang bersifat fungsional. Kedua, yang mementingkan aspek sosiolinguistik sebagai latar dan situasi penggunaan bahasa.

3. Pelajaran bahasa Arab dengan pendekatan komunikatif sebaiknya bersifat kreatif yang bisa membangkitkan minat belajar bahasa Arab dan motivasi berperan dalam aktivitas komunikatif, serta menciptakan situasi yang mendukung tujuan komunikasi yang sesuai dengan kebutuhan dan minat pelajar terhadap bahasa Arab.

\section{Simpulan}

Dari penjelasan di atas, dapat ditarik simpulan berikut:

1. Pada hakikatnya, belajar bahasa ada-lah belajar berkomunikasi. Karena itu, pelajaran bahasa Arab di madrasah harus diarahkan untuk meningkatkan kemampuan siswa dalam berkomunikasi, baik secara lisan maupun tulisan. Bahasa sebagai sarana komunikasi digunakan dalam bermacam-macam fungsi dan disajikan dalam konteks yang bermakna, tidak dalam bentuk kalimat lepas.

2. Terdapat dua corak pendekatan komunikatif. Pertama, yang masih mementingkan aspek gramatika yang bersifat fungsional. Kedua, yang mementingkan aspek sosiolinguistik sebagai latar dan situasi penggunaan bahasa.

3. Pelajaran bahasa Arab dengan pendekatan komunikatif sebaiknya bersifat kreatif yang bisa membangkitkan minat belajar bahasa Arab dan motivasi berperan dalam aktivitas komunikatif, serta menciptakan situasi yang mendukung tujuan komunikasi yang sesuai dengan kebutuhan dan minat pelajar terhadap bahasa Arab.

4. Tujuan pelajaran bahasa dalam pen-dekatan komunikatif adalah agar siswa memiliki kompetensi berkomunikasi dengan menggunakan bahasa yang dipelajarinya dalam berbagai situasi sosial dan fungsional.

\section{Daftar Pustaka}

Ainin, Moh., dkk., Evaluasi dalam Pelajaran Bahasa Arab, Malang: Misykat, 2006.

Ari in, "Penerapan Pendekatan Komunikatif dalam Pengajaran Gramatika di SLTP Negeri I Kota

Malang". Tesis, Program Studi Pendidikan Bahasa Indonesia, PPs. UM, 2002.

Arikunto, Suharsimi dan Cepi Safruddin Abdul Jabar, Evaluasi Program Pendidikan, Jakarta: Bumi Aksara, 2008.

Azies, Furqanul dan A. Chaedar Alwasilah, Pengajaran Bahasa Komunikatif, Teori dan Praktek, Bandung: PT. Remaja Rosda karya, 2000.

Badri, Kamal Ibrahim dan Shalih Muhammad Nashir, Usus Ta'lîm al-Lughah al-Ajnabiyyah, Jakarta: LIPIA, t.th.

Badri, Kamal Ibrahim, "Thuruq Ta'lîm al-Lughah al-Ajnabiyyah" dalam al-Thuruq al-'A mmah fîTadrîs al-Lughah, Jakarta: LIPIA, t.th.

Brown, H. Douglas, Prinsip Pelajaran dan Pengajaran Bahasa, alih bahasa: Noor Cholis dan Yusi Avianto Pareanom, Jakarta: Kedutaan Amerika Serikat, 2007.

Canale, Michael dan Merrill Swain, Theoretical Bases of Communicative Approaches to Second

Language Teaching and Testing, Oxford: Oxford University Press, 1980.

Djiwandono, M. Soenardi, Tes Bahasa dalam Pengajaran, Bandung: ITB, 1996.

, Tes Bahasa, Pegangan Bagi Pengajar Bahasa, Jakarta: PT. Indeks, 2008.

Effendi, Ahmad Fuad, Metodologi Pengajaran Bahasa Arab, Malang: Misykat, 2005. 
Huda, Nuril, “Metode Audiolingual Vs. Metode Komunikatif: Suatu Perbandingan”, Makalah, Pertemuan Linguistik Lembaga Bahasa Atmajaya, Universitas Katolik Atmajaya, Jakarta, September 1987 LarsenFreeman, Diane, Techniques and Principles In Language Teaching, Oxford: Oxford University Press, 1980.

Murtadho, Nurul, Silabus Matakuliah Keterampilan Berbicara Dengan Pendekatan Komunikatif Untuk Mahasiswa Program Pendidikan Bahasa Arab JPBA FPBS IKIP Malang. Tesis, Tidak Diterbitkan, Malang: IKIP Malang, 1991.

Muslich, Masnur, KTSP (Kurikulum Tingkat Satuan Pendidikan) Dasar Pemahaman dan Pengembangan, Jakarta, Bumi Aksara: 2007.

Nababan, P.W.J, Ilmu Pragmatik (Teori dan Penerapannya), Jakarta: Depdiknas, 1987.

Nawawi, Mukhson, "Landasan Teoritis Filoso is Metode Pengajaran Bahasa”, Makalah, Muktamar Internasional ADIA di Fakultas Humaniora dan Budaya UIN Maliki Malang, 12-14 Oktober 2010 Nurgiyantoro, Burhan, Penilaian Pelajaran Bahasa Berbasis Kompetensi, Yogyakarta: BPFEYogyakarta, 2010.

Prasetyanti, Retnayu, Modul Evaluasi Pelajaran Seni Budaya, Surabaya: UNESA, 2008. Purwanto, Ngalim, Prinsip-prinsip dan Teknik Evaluasi Pengajaran, Bandung, PT. Remaja Rosda Karya, 1984

Richards, Jack C. dan Theodore S. Rodgers, Approaches and Methods in Language Teaching, Cambridge, Cambridge University Press, 1992.

Richards, Jack C., Curriculum Development in Language Teaching, terjemah Nashir bin 'Abdullah bin Ghali dan Shalih bin Nashir al-Syuwairikh (Tathwîr Manâhij Ta'lîm al-Lughah), PDF.

Sumardi, Muljanto (ed), Berbagai Pendekatan dalam Pengajaran Bahasa dan Sastra, Jakarta: Pustaka Sinar Harapan, 1996.

Sya i’i, Imam, Kompetensi Kebahasaan dan Kompetensi Komunikatif dalam Pengajaran Bahasa, Malang: IKIP, 1991.

Tarigan, Henry Guntur, Pengajaran Kompetensi Bahasa, Bandung: Angkasa, 1990.

Thu'aimah, Rusydi Ahmad dan Mahmud Kamil al-Naqah, Ta'lîm al-Lughah Ittishâliyan Baina alManâhij wa al-Istirâtîjiyyah, Rabath: ISESCO, 2006.

-, Ta'lîm al-'Arabiyyah li-Ghair al-Nâthiqîn bihâ Manâhijuhu wa Asâlîbuhu, Rabath: Isesco, 1989. 

